\title{
PENGARUH STRATEGI PEMBELAJARAN DAN EFIKASI DIRI TERHADAP KEMAMPUAN MEMBACA SISWA KELAS V SDN SERDANG 07 JAKARTA
}

\author{
Kusriani $^{1}$, Muhammad Japar ${ }^{2}$, Juhana ${ }^{3}$ \\ 1,3 Universitas Terbuka \\ ${ }^{2}$ Universitas Negeri Jakarta
}

\begin{abstract}
The purpose of this study was to know 1) the effect of instructional strategies, in which directed reading thinking activity and mind mapping on reading understanding, 2) the effect of self-efficacy on reading understanding, 3) the interaction of instructional strategies and self-efficacy on reading understanding. This study was conducted on fifth grade of SDN Serdang 07 with population of 112 students. The samples used were 56 students. The independent variable of the study was instructional strategies which consists of directed reading thinking activity and mind mapping and students' self-efficacy, on the other hand the dependent variable was reading comprehension. Variables were measured by reading test and self-efficacy questioner. Data was analyzed with test normality, test of homogeneity, and analysis of variance two-way by excel of windows. The result shows that 1) Reading comprehension was effected by instructional strategies 2) The self-efficacy had no effect on reading comprehension. 3) There was no interaction between self-efficacy and instructional strategies.
\end{abstract}

Keyword: Instructional Strategies, Self-Efficacy, Reading Comprehension.

\begin{abstract}
Abstrak: Penelitian ini bertujuan untuk mengetahui 1) pengaruh strategi pembelajaran terhadap kemampuan membaca pemahaman, 2) pengaruh efikasi diri terhadap kemampuan membaca pemahaman, 3) interaksi strategi pembelajaran dan efikasi diri terhadap kemampuan membaca pemahaman. Penelitian ini dilakukan pada siswa kelas V SDN Serdang 07 dengan populasi 112 siswa. Sampel yang digunakan sebanyak 56 siswa. Variabel independen pada penelitian ini adalah strategi pembelajaran yang terdiri dari data dan mind mapping dan efikasi diri, sedangkan variabel dependen adalah kemampuan membaca pemahaman. Pengukuran variabel dilakukan menggunakan tes dan kuesioner. Analisis data dilakukan dengan menggunakan teknik analisis deskriptif normalitas, homogenitas dan anava dua jalur. Untuk analisis deskriptif menggunakan excel for windows. Berdasarkan hasil penelitian dapat disimpulkan bahwa: 1) Kemampuan membaca pemahaman dipengaruhi oleh strategi pembelajaran. 2) Efikasi diri tidak mempengaruhi kemampuan membaca pemahaman siswa. 3) Tidak ada interaksi antara strategi pembelajaran dan efikasi diri.
\end{abstract}

Kata Kunci: Strategi Pembelajaran, Efikasi Diri, Membaca Pemahaman.

\footnotetext{
' Universitas Terbuka, Email: dkusrianikustakn回gmail.cam

${ }^{2}$ Universitas Negeri Jakarta, Email: mjapar国uni.ac.id

${ }^{3}$ Universitas Terbuka, Email: juhana国ecampus.ut.ac.id
} 


\section{PENDAHULUAN}

Membaca merupakan kunci dari pendidikan, maksudnya adalah orang yang sering membaca, pendidikannya akan maju dan ia akan memiliki wawasan yang luas. Membaca memiliki banyak fungsi dalam kehidupan manusia, bahkan membaca merupakan faktor terpenting dalam keberhasilan akademik seseorang. Dengan demikian diharapkan peserta didik mempunyai kemampuan membaca yang baik. Dengan membaca, peserta didik akan mendapatkan informasi dan pengetahuan pada bidang studi lain seperti matematika, sosial, dan bidang ilmu lainnya (Calkins, 2001, hlm. 13).

Penelitian yang dilakukan oleh Sidebang (2016) menemukan bahwa pengajaran strategi pembelajaran meningkatkan kemampuan membaca. Hal ini menunjukkan bahwa ketika siswa mengalami strategi pengajaran pemahaman langsung, maka pemahaman bacaan atau topik bacaan meningkat berkat strategi pembelajaran itu. Strategi pembelajaran untuk meningkatkan membaca antara lain strategi directed reading, thinking activity, dan strategi mind mapping.

Strategi directed reading thinking activity adalah strategi dalam pembelajaran bahasa yang menitik beratkan pada interaksi siswa dengan teks, karena siswa membuat prediksi dan membuktikan apakah prediksinya benar atau tidak ketika mereka membaca. Strategi ini dikembangkan oleh Russel G. Stauffer pada tahun 1969. Abidin (2012, hlm. 80) melaksanakan strategi directed reading thinking activity dalam beberapa tahapan pembelajaran berikut ini.

1) Prabaca: Kegiatan dilakukan pada saat, siswa sebelum membaca, yaitu a) bahan bacaan diperkenalkan oleh guru dengan menyampaikan informasi tentang isi bacaan, dan b) siswa membuat dugaan tentang teks yang akan dibacakan. Jika siswa belum mampu, guru harus menantang siswa tersebut untuk membuat dugaan. Cobalah membuat banyak dugaan sehingga muncul kelompok dengan pendapat berbeda. 2) Membaca:

Kegiatan ini dilakukan siswa sambil membaca, yaitu a) siswa membaca dalam diam pada teks untuk mengecek prediksi yang telah dibuat. Pada tahap ini guru harus mampu membimbing siswa dalam kegiatan membaca untuk menemukan makna membaca. b) Tes prediksi Pada tahap ini siswa diwajibkan untuk mengecek prediksi yang telah dibuat. Jika prediksi yang dibuat salah, siswa harus bisa menunjukkan kesalahannya dan mampu memberikan gambaran baru tentang isi wacana yang sebenarnya. 3) Pascabaca: Kegiatannya adalah memberikan pelatihan dasar. Tahapan ini dilakukan siswa untuk merangsang kemampuan berpikirnya. Beberapa kegiatan yang dilakukan siswa adalah tes ulang cerita, menceritakan kembali cerita, menggambar, dan menggambar diagram.

Strategi mind mapping ini diperkenalkan kepada siswa untuk meningkatkan daya ingat dan pemahaman siswa terhadap suatu materi pelajaran dengan memberikan kebebasan kepada mereka untuk berpikir dalam mengembangkan konsep yang telah dipelajari sebelumnya.

Langkah-langkap penerapan strategi mind mapping sebagai berikut.

1) Prabaca, guru memperkenalkan judul bacaan. Guru menuliskan judul di tengah papan tulis dan memberikan garis-garis yang akan diisi siswa setelah membaca. 2) Membaca, siswa membaca teks dalam hati. 3) Pascabaca, siswa berpasangan membuat mind map dari bacaan yang sudah dibaca. Dalam membuat catatan berbentuk mind map (peta pikiran), rangkaian huruf yang menjadi topik, subtopik, atau kata kunci bisa digunakan dalam huruf kapital agar tulisan bisa mudah dibaca dan dipahami oleh orang lain.

Untuk meraih pembelajaran yang berhasil, efikasi diri sebagai satu dari banyak faktor dalam diri seseorang yang akan memberikan keyakinan yang kuat bahwa ia mampu mendapatkan hasil tertentu sesuai dengan keyakinannya. 
Menurut Schunk (2012, hlm. 215), Efikasi diri sebagai satu hal yang sangat berperan penting terhadap motivasi dan keberhasilan. Individu yang memiliki efikasi diri akan menggerakkan motivasi untuk melaksanakan tugas yang diberikan dan yakin hasilnya akan sesuai dengan dengan harapan. Keyakinan itu membuat seseorang akan berusaha untuk mendapatkan hasil belajar yang tinggi.

Pandangan kognitif yang penting untuk dikembangkan oleh anak yaitu efikasi diri yang merupakan suatu bentuk kepercayaan seseorang dalam menguasai sesuatu dan menghasilkan sesuatu yang baik (Santrock, 2011, hlm. 225). Efikasi diri dipopulerkan oleh Bandura. Efikasi diri adalah variabel pribadi yang penting, dikombinasikan dengan tujuan tertentu dan khusus, ditambah pemahaman tentang pencapaian, serta akan menentukan perilaku di masa depan (Rahyubi, 2012, hlm. 112).

Berdasarkan paparan di atas, dipandang perlu untuk melakukan suatu penelitian tentang kemampuan membaca pemahaman dengan strategi pembelajaran dan efikasi diri sebagai variabel bebas dan kemampuan membaca pemahaman sebagai variabel terikat yang dilaksanakan di Sekolah Dasar Negeri Serdang 07 di Kecamatan Kemayoran.

Tujuan penelitian ini ialah untuk mengetahui pengaruh strategi pembelajaran dan efikasi diri terhadap kemampuan membaca pemahaman pada siswa kelas $\mathrm{V}$ di SDN Serdang 07 Jakarta.

\section{METODOLOGI PENELITIAN}

Penelitian ini menggunakan pendekatan kuantitatif, dengan metode penelitian quasi eksperimen. Penelitian ini menggunakan dua kelompok eksperimen yaitu kelas eksperimen dan kelas control. Kelas eksperimen adalah yang belajar dengan strategi directed reading thinking activity dan kelas control adalah yang belajar dengan strategi mind mapping. Metode eksperimen ini digakan untuk meneliti ada tidaknya hubungan sebab akibat dengan cara memberikan perlakuan terhadap kedua kelompok eksperimen dengan diberi perlakuan yang berbeda.

Data kemampuan membaca pemahaman didapatkan melalui pemberian tes objektif dan data tingkat efikasi siswa didapat melalui instrumen angket efikasi diri. Populasi penelitian ini adalah seluruh siswa kelas V SDN Serdang 07, Kemayoran, Jakarta Pusat, DKI Jakarta. Sampel penelitian menggunakan teknik clustered sampling yang didapatkan secara diundi, didapatlah kelas V A sebagai kelas eksperimen dan kelas V B sebagai kelas kontrol. Distribusi sampel dalam disajikan dalam tabel.

Tabel 1. Distribusi Sampel pada Tiap Kelas Menurut Perlakuan

\begin{tabular}{|c|c|c|c|}
\hline \multirow[b]{2}{*}{$\begin{array}{c}\text { Efikasi } \\
\text { Diri }\end{array}$} & \multicolumn{2}{|c|}{$\begin{array}{c}\text { Strategi } \\
\text { pembelajaran }\end{array}$} & \multirow[b]{2}{*}{ Jumlah } \\
\hline & $\begin{array}{c}\text { DRTA } \\
\left(\mathrm{A}_{1}\right)\end{array}$ & $\begin{array}{c}\text { Mind } \\
\text { mapping } \\
\left(\mathrm{A}_{2}\right)\end{array}$ & \\
\hline $\begin{array}{l}\text { Tinggi } \\
\left(\mathrm{B}_{1}\right)\end{array}$ & 14 & 14 & 28 \\
\hline $\begin{array}{l}\text { Rendah } \\
\left(\mathrm{B}_{2}\right)\end{array}$ & 14 & 14 & 28 \\
\hline Jumlah & 28 & 28 & 56 \\
\hline
\end{tabular}

Data analisis dalam penelitian ini menggunakan analisis varian dua jalur. Tes hipotes ini dinilai mempunyai keuntungan dapat membandingkan antara variabel dan pengulangannya. Tes anava dua jalur digunakan untuk melihat pengaruh strategi pembelajaran dan efikasi diri terhadap kemampuan membaca.

\section{HASIL PENELITIAN DAN PEMBAHASAN}

Bagian ini penulis mencoba untuk menyampaikan hasil penelitian yang dapat dijabarkan melalui tabel anova dua jalur yang didapatkan kemudian diringkas dan disajikan dalam tabel berikut. 
Tabel 2: Hasil Anova

\begin{tabular}{lcrccr} 
ANOVA & \multicolumn{1}{c}{ Source of } \\
Variation & $S S$ & Df & MS & $F$ & \multicolumn{1}{c}{$P$-value } \\
\hline Sample & 401,7857 & 1 & 401,7857 & 2,354388 & 0,130993 \\
Columns & 1607,143 & 1 & 1607,143 & 9,417552 & 0,00341 \\
Interaction & 79,36508 & 1 & 79,36508 & 0,465064 & 0,498293 \\
Within & 8874,008 & 52 & 170,654 & & \\
& & & & & \\
Total & 10962,3 & 55 & & & \\
\hline
\end{tabular}

Berdasarkan analisis di atas ringkasan hasil tes hipotesis sebagai berikut.

Hasil tes hipotesis yang pertama sesuai dengan kriteria hipotesis yang pertama. Hasil analisis menunjukkan $P$ value $\leq 0,05(5 \%)$, artinya koefisien Nilai $\mathrm{F}$ adalah signifikan. Artinya, dapat dikatakan $\mathrm{H}_{1}$ diterima, dan $\mathrm{H}_{0}$ ditolak. Kesimpulannya, strategi pembelajaran mempengaruhi secara signifikan kemampuan membaca pemahaman.

Rata-rata tes membaca pemahaman siswa yang belajar dengan strategi directed reading thinking activity lebih tinggi daripada rata-rata tes membaca pemahaman siswa yang belajar dengan strategi mind mapping. Hal ini disebabkan siswa aktif berpikir selama membaca untuk memahami bacaan. Hal ini sesuai dengan Zulhidah (2011, hlm. 28) yang mengatakan bahwa strategi directed reading thinking activity merangsang berpikir dan mengembangkan perkiraan isi teks bacaan yang membantu menginterpretasi isi teks dan memahami isi teks.

Guzzetti (2002, hlm. 135) juga mengatakan bahwa strategi directed reading thinking activity melibatkan siswa aktif dalam membaca dan memformulasikan prediksi-prediksi, sehingga guru berperan hanya sebagai fasilitator. Keaktifan siswa dalam proses membaca dapat dilihat dalam rangkaian atau tahapan membaca. Strategi pembelajaran directed reading thinking activity mempunyai tahapan sebelum membaca membuat prediksi isi bacaan yang akan dibaca. Tahapan membaca, membuktikan bahwa prediksi sebelum membaca adalah benar atau tidak. Tahapan setelah membaca, mengaktifkan proses berpikir dengan menceritakan kembali. Semua tahapan itu adalah proses berpikir yang melibatkan pembaca dalam menggunakan pengalamannya dalam mengkonstruksi ide penulis dalam bacaan dukung Graves (2007, hlm. 242)

Hasil tes hipotesis kedua menunjukkan $P$-value $\geq 0,05 \quad(5 \%)$. Sehingga dapat dikatakan bahwa tidak ada pengaruh signifikan efikasi diri terhadap kemampuan membaca pemahaman.

Efikasi diri tidak banyak berpengaruh terhadap kemampuan membaca. Hal tersebut disebabkan efikasi diri merupakan cara pandang seseorang terhadap kemampuan dan ketidakmampuan dalam menyelesaikan tugas yang diberikan. Efikasi diri ini hanya menekankan determinasi seseorang kepada kemampuannya sendiri terhadap tugas yang diberikan dan kurang ditekankan pada kemampuan dan ketrampilan yang dimiliki secara nyata. Terlebih lagi efikasi bersifat subjektif (Kristiyanti, 2016, hlm. 84) karena ada orang yang secara objektif mampu melaksanakan tugas yang diberikan, tetapi dirinya sendiri merasa tidak mampu melaksanakannya, atau sebaliknya. Menilai diri sendiri secara berlebihan atau kurang, mungkin juga karena kurang pengalaman pada anak usia sekolah dasar. Hal ini juga dapat ditinjau dari pertimbangan bahwa anak usia 10 tahun masih terus berkembang rasa kepercayaan dirinya (Megawangi, 2007, hlm. 74)

Hasil tes hipotesis kedua menunjukkan P-value $\geq 0,05$ (5\%). Dapat dikatakan bahwa tidak ada interaksi antara strategi pembelajaran terhadap kemampuan membaca. Strategi pembelajaran berdiri sendiri dalam mempengaruhi kemampuan membaca dan tidak dipengaruhi oleh efikasi diri.

\section{KESIMPULAN}

Penelitian tentang kemampuan membaca pemahaman dengan strategi pembelajaran dan efikasi diri sebagai 
variabel bebas dan kemampuan membaca pemahaman sebagai variabel terikat yang dilaksanakan di SDN Serdang 07 dapat disimpulkan sebagai berikut ini.

1. Kemampuan membaca pemahaman dipengaruhi oleh strategi pembelajaran dan siswa yang belajar dengan strategi directed reading thinking activity lebih tinggi hasilnya daripada siswa yang belajar dengan strategi mind mapping .

2. Kemampuan membaca pemahaman tidak dipengaruhi oleh efikasi diri.

3. Tidak terdapat interaksi antara strategi pembelajaran dengan efikasi diri terhadap kemampuan membaca pemahaman siswa.

Sesuai dengan simpulan yang sudah diuraikan di atas, saran yang dapat diajukan berdasarkan hasil penelitian dan simpulan yang telah dipaparkan yakni sebaiknya diajarkan juga strategi pembelajaran dalam kegiatan membaca agar kemampuan membaca pemahaman siswa lebih baik. Strategi pembelajaran yang dipakai bisa menggunakan strategi directed reading thinking activity, mind mapping, atau yang lainnya. Hal tersebut dilakukan karena memang terbukti bahwa strategi pembelajaran mempengaruhi kemampuan membaca pemahaman siswa.

\section{DAFTAR PUSTAKA}

Abidin, Y. (2012). Pembelajaran Membaca Berbasis Pendidikan Karakter. Bandung: Refika Aditama.

Calkins, Lucy McCoimick. (2001). The Art of teaching Reading. London: Longman

Graves, Michael F. (2007). Teaching Reading in the $21^{\text {st }}$ Century. London: Pearson

Guzzetti, Barbara J. (2002). Literacy in America: An Encyclopedia of History, Theory and Practice. California: ABC Clio

Megawangi, Ratna. (2007). Semua Berakar pada Karakter. Depok: Universitas Indonesia.

Rahyubi, Heri. (2012). Teori-teori Belajar dan Aplikasi Pembelajaran Motorik
Deskripsi dan Tinjauan Kritis. Bandung: Nusa Media

Santrock, John W. (2011). Educational Psychology. New York: McGraw Hill Education

Schunk. Dale H. (2012). Learning Theories an Educational Perspective. Yogyakarta: Pustaka Pelajar.

Sidebang, Restio. (2016). Pengaruh Strategi Pembelajaran dan Motivasi Belajar Terhadap Kemampuan Membaca Pemahaman Teks Narasi Siswa. Jurnal Tematik. Vol. 6 No.3 DOI: https://doi.org/10.24114/jt.v6i3 .4543

Zulhidah. (2011). Strategi Pembelajaran Reading Comprehension. Riau: UIN Sultan Syarif Kasim 